\title{
PERSAHABATAN DALAM PERSPEKTIF NEO-THOMISME YOSEPH PIEPER
}

Donatus Sermada

\begin{abstract}
Neo-thomism is a school of philosophy that revives the philospical-theological thoughts of Thomas Aquinas. This article contains of the thoughts of Yoseph Pieper, a German Catholic philosopher who follows Neo-Thomism. Joseph Pieper's works show their root to Thomas Aquinas' philosophy. Pieper's concepts on man and society, as discussed in this article, become the writer's perspective to convey the concept of friendship which concluded from Pieper's concept about an ideal Christian: a man of faith, hope, love, temperance, justice, courage, and prudence.
\end{abstract}

Keywords: Yoseph Pieper, Neo-Thomism, friendship.

\begin{abstract}
Abstrak
Neo-Thomisme merupakan sebuah aliran filsafat yang menghidupkan kembali pemikiran filosofis-teologis Thomas Aquinas. Artikel ini berisikan tentang pemikiran Yoseph Pieper, seorang filsuf Katolik yang berkebangsaan Jerman dan berhaluan Neo-Thomisme. Karya-karya Yoseph Pieper memperlihatkan keberakarannya pada Filsafat Thomas Aquinas. Konsep Pieper tentang manusia dan masyarakat, sebagaimana dipaparkan dalam artikel ini, menjadi perspektif penulis untuk mengemukakan konsep tentang persahabatan yang disimpulkan dari konsep Pieper tentang sosok manusia kristiani yang ideal: manusia yang beriman, manusia yang berharap, manusia yang mencinta, manusia yang bijak, manusia yang adil, manusia yang berani dan manusia yang ugahari.
\end{abstract}

Kata kunci: Yoseph Pieper; Neo-Thomisme; persahabatan. 


\section{Pendahuluan}

Tema hari studi 2020 untuk mengisi perayaan pesta emas berdirinya STFT Widya Sasana Malang berbunyi “Kamulah Adalah SahabatKu”. Penulis menelusuri etika persahabatan dalam perspektif pemikiran filosofisteologis Yoseph Pieper, seorang filsuf Katolik berkebangsaan Jerman dan berhaluan Neo-Thomisme. Penjelasan tentang etika persahabatan dalam perspektif Pieper didahului oleh peneropongan penulis tentang konsep manusia dalam terang pemikiran Neo-Thomisme dan disusul dengan uraian tentang tokoh Yoseph Pieper dan sosok manusia kristiani menurut Pieper.

\section{Konsep tentang Manusia dalam Neo-Thomisme}

Neo-Thomisme adalah satu gerakan pemikiran filosofis-teologis yang menghidupkan kembali pokok pemikiran Thomas Aquinas sejak abad 19 hingga mencapai puncak perkembangannya pada pertengahan abad 20 . Bersamaan dengan berkembangnya pemikiran Neo-Kantianisme yang menghidupkan kembali pokok pemikiran Kant, para pemikir Katolik didorong oleh Paus Leo ke XIII dalam ensikliknya “Aeterni Patris” (1879) untuk membaharui pokok pemikiran Thomas Aquinas dalam rangka untuk menjawabi tantangan pemikiran modern tentang manusia dan masyarakat. ${ }^{1}$ Tokoh-tokoh Katolik yang berhaluan Neo-Thomisme adalah seperti Jacques Maritain, Joseph Lagrance, Josef Pieper, Karl Rahner, Emerith Coreth, Bernard Lonergan, Alasdair Maclntyre dan sebagainya. Pemikiran modern yang sangat dasyat berdampak pada berpengaruhnya paham atheisme, agnostisisme dan sekularisme adalah pemikiran Kant dan Neo-Kantianisme, dan dampak dari pemikiran modern aliran inilah yang menjadi sasaran kritik para pemikir Neo-Thomisme.

Thomas Aquinas mengembangkan konsep biblis tentang manusia, bahwa manusia itu diciptakan menurut gambaran Allah. ${ }^{2}$ Karena manusia

1 Robert Audi (ed.), The Cambridge Dictionary of Philosophy. New York: Cambridge University Press, 1995, hlm. 527.

2 Oelmueller Doelle-Oelmueller Geyer, Philosophische Arbeitsbuecher 7 Diskurs: Mensch. Muenchen: Wilhem Fink Verlag, 1990, hlm. 113-114. 
itu merupakan gambaran Allah, maka di dalam diri manusia terdapat sisi ilahi yang disebut jiwa. Jiwa dan badan menurut Thomas terbentuk dalam satu kesatuan substansial yang berdiri sendiri. Jiwa menjelmakan kemampuannya pada badan dan hanya bisa dimengerti melalui badan manusia, sementara badan manusia mendapat kemampuannya dari jiwa untuk hidup. Kesatuan substansial jiwa dan badan ini disebut "pribadi" (person). Kemampuan tertinggi jiwa manusia adalah akal budi manusia yang berakar dalam akal budi ilahi. ${ }^{3}$ Interaksi antara manusia yang satu dengan manusia yang lain tidak dapat dihindari, karena manusia dari kodratnya adalah makhluk sosial, dan interaksi sosial ini justru membentuk kehidupan keluarga, masyarakat dan negara. Persahabatan antara manusia yang satu dengan manusia yang lain adalah salah satu bentuk interaksi sosial yang berjalan seimbang dan setara, karena masing-masing pribadi dalam relasi itu mencerminkan sosok dan gambar Allah. Tidak ada musuh dan permusuhan dalam konteks pemikiran Thomas ini.

Untuk mengatur dan menjamin interaksi sosial baik dalam bentuk yang kecil seperti keluarga maupun dalam bentuk yang lebih besar dari interaksi itu seperti masyarakat dan negara, menurut Thomas sudah tersedia hukum ilahi untuk menuntun kehidupan berkeluarga, kehidupan bermasyarakat dan kehidupan bernegara. Hukum ilahi dibedakan dari hukum kodrat dan hukum moral. Hukum ilahi didefinisikan oleh Thomas sebagai "akal budi untuk memerintah segala sesuatu, akal budi yang adalah Allah sendiri sebagai penguasa alam semesta". ${ }^{4}$ Segala sesuatu di atas dunia yang adalah ciptaan Allah berada di bawah hukum ilahi. Hukum kodrat atau disebut juga hukum alam merupakan aturan pokok yang melekat dan menyatu pada manusia, dan perbuatan manusia dituntun oleh hukum kodrat ini. Hukum kodrat ini berada di bawah tuntunan akal budi manusia dalam fungsi praktis akal budi, yaitu untuk menghasilkan pedoman praktis bagi

3 Harun Hadiwijono, Dr., Sari Sejarah Filsafat Barat 1. Yogyakarta: Penerbit Kanisius, 1980, hlm. 110-111.

4 "Plan (ratio) der Regierung aller Dinge, der in Gott als dem Herrscher des Weltalls besteht". Wieland G., Ethik als praktische Wissenchaft. Dalam Philosophische Propaedeutik Band 2: Ethik.Honnefelder/Krieger (Ed.) Muenchen: Wilhem Fink Verlag, 1996, hlm. 62. 
perbuatan manusia mencapai kebaikan atau kebahagiaan. Akal budi dalam fungsi teoretisnya adalah untuk mengenal dan mengetahui kebenaran; artinya, mencapai kebenaran adalah sasaran pengetahuan melalui akal budi yang berfungsi secara teoretis. ${ }^{5}$ Hukum kodrat yang menyatu pada manusia ini bukanlah sesuatu yang otonom, tetapi berakar pada hukum ilahi dan mengambil bagian dalam hukum ilahi. Hukum moral merupakan bagian dari hukum kodrat manusia, dan fungsi hukum moral adalah untuk mengatur dan menentukan baik-buruknya perbuatan manusia. Hukum moral berada di bawah tanggung jawab kehendak bebas dan akal budi manusia dalam relasinya dengan hukum ilahi sebagai penuntun tanggung jawab manusia untuk bertindak baik.

Akan tetapi, bagaimana kita mengenal hukum ilahi di dalam perbuatan manusia? Interaksi sosial yang membentuk masyarakat dan negara menurut Thomas ada untuk mencapai "kebaikan bersama" atau kesejahteraan umum (Bonum Communae). Kebaikan bersama itulah prinsip moral kolektif yang perlu menjiwai pembuatan dan penciptaan undang-undang dan peraturan masyarakat dan negara. Di dalam hukum moral itu bersinarlah hukum ilahi yang ditangkap langsung melalui suara hati dan akal budi manusia. Hukum moral yang dikenal dan ditangkap langsung bersifat universal, seperti: "Lakukanlah yang baik dan jauhkanlah yang jahat"; "jangan membunuh"; "jangan menambah derita orang." Hanyalah dibutuhkan kemampuan budi praktis dan kehendak bebas manusia untuk mengaplikasikan hukum moral yang dijiwai oleh hukum ilahi itu ke dalam hukum positif. Kehidupan bermasyarakat dan bernegara berlandaskan pada hukum moral itu yang tertuang secara terbatas dalam cetusan dan rumusan peraturan dan undang-undang. Karena itu, kebijakan dan tindakan negara tidak boleh diukur dan dinilai semata-mata menurut rumusan dan bunyi undang-undang dan peraturan-peraturan, tetapi haruslah diilhami, dicerahkan dan diterangi oleh hukum ilahi, yaitu Allah sendiri sebagai kebaikan tertinggi,

5 Honnefelder L., Person und Menschenwuerde. Dalam Philosophische Propaedeutik Band 2: Ethik. Honnefelder/Krieger. Muenchen: Wilhem Fink Verlag, 1996, hlm. 223-224.

6 Wieland G., Ethik als...Op.cit., hlm. 62-66. 
demi pencapaian kesejahteraan bersama atau kebaikan bersama di atas dunia.

Pemikiran dasar Thomas Aquinas tentang manusia dan masyarakat seperti itulah yang dikembangkan dan dikontekstualisir oleh para pemikir Neo-Thomisme. Mereka mengkritik gagasan dasar filsafat modern yang menolak adanya hukum ilahi dan prinsip meta-etis seperti kebaikan dan kebahagiaan sebagai tujuan (teleos) perbuatan manusia. Dengan begitu, etika persahabatan dalam pandangan filsafat modern bersifat tertutup, dalam arti bahwa prinsip kebaikan dan kebahagiaan itu melulu bersifat manusiawi, karena hukum ilahi dalam arti Allah sebagai kebaikan dan kebahagiaan sudah disangkal baik secara teoretis maupun secara praktis. Meskipun sangat sedikit terdapat pemikiran yang menjadi milik bersama para pemikir NeoThomisme, tetapi usaha mereka untuk kembali ke gagasan dasar Thomas tentang manusia dan rasa kecurigaan yang kuat terhadap konsep filsafat modern tentang manusia sungguh sangat mengemuka. Kata"neo" (baru) pada frasa "Neo-Thomisme" mengacu pada penerapan gagasan dasar Filsafat Thomas Aquinas sebagai mata pisau untuk membedah borok-borok kelemahan filsafat modern. Kita mengemukakan salah satu contoh tentang mata pisau itu, dan kita angkat tokoh Alaisdair Maclntyre yang mengeritik etika modern dari sudut pandang teori keutamaan.

Etika modern yang dikritik oleh Maclntyre berlandaskan pada konsep filsafat modern tentang manusia yang dijadikan sebagai titik pusat untuk meneropong segala sesuatu. Panglima tertinggi untuk menuntun hidup manusia menurut filsafat modern adalah rasionalitas manusia (akal budi dan kegiatan akal budi manusia). Perbuatan baik tidak diukur oleh suatu prinsip kebaikan yang berada di luar manusia, tetapi oleh manusia sendiri melalui kehendak bebas dan kekuatan rasionalnya. Dengan demikian, prinsip moral etika modern bersifat sangat subyektif. Kebaikan secara teoretis adalah hasil kerja akal budi manusia dalam proses penilaian manusia terhadap baik-buruknya suatu perbuatan manusia. Kelemahan etika modern yang berlandaskan pada konsep manusia seperti itu menurut Maclntyre terletak dalam pengabaian sisi emosi dan affeksi yang berperan kuat pada proses pembentukan watak dan keutamaan manusia. Selain itu, prinsip moral subyektif yang menentukan perbuatan baik manusia dalam pemahaman 
filsafat modern menurut Maclntyre telah kehilangan unsur teleologis (tujuan) yang berada di luar diri manusia. Artinya, menurut Maclntyre dengan adanya unsur teleologis yang berada di luar manusia, setiap perbuatan manusia untuk menjadi seorang manusia yang baik perlu mempunyai sasaran yang jelas dan obyektif, dan sasaran perbuatan ini bukan mengacu pada diri manusia, tetapi harus mengarah pada sesuatu kebaikan yang memiliki hakekatnya sendiri terpisah dari manusia. ${ }^{7}$ Bahasa teologis tentu menyebut Allah sebagai kebaikan, sementara bahasa filsafat menyebutnya sebagai sebuah prinsip meta-etis. Persahabatan dalam terang pemikiran Maclntyre perlu bertumpu pada prinsip meta-etis itu.

\section{Yoseph Pieper dan Konsepnya tentang Manusia Kristiani}

Yoseph Pieper adalah seorang filsuf katolik yang berkebangsaan Jerman. Beliau lahir pada tanggal 4 Mei 1904 di Elte, Rheine, Nord Rhein Westfalen, Jerman, dan meninggal 6 Nopember 1997 di Muenster, Jerman. Ia belajar Filsafat, Hukum dan Sosiologi di Universitas Berlin dan Muenster. Setelah menyelesaikan studinya, ia semula berkiprah sebagai dosen sosiologi, tetapi kemudian ketika meraih jabatan akademis sebagai profesor, beliau menerjunkan dirinya di bidang filsafat, khususnya filsafat Anthropologi yang berbasiskan pada pemikiran Thomas Aquinas. Sebagai profesor, beliau mengajar Filsafat Anthropologi di Fakultas Teologi Katolik di Universitas Muenster dan mengajar Filsafat Agama, utamanya Filsafat Kristen di Fakultas Filsafat Universitas Muenster dari tahun 1950-1976. Karena pemikirannya yang dituangkannya dalam banyak hasil karya filsafatnya berakar kuat pada pemikiran Thomas Aquinas, maka baik Paus Yohanes Paulus ke II maupun Paus Benediktus XVI dalam kotbah dan dokumen mereka sering menyebut nama Yoseph Pieper si pemikir katolik ini.

Hampir semua karya tulisannya sudah diterjemahkan ke dalam bahasa Inggris, meskipun dia sendiri menulis dalam bahasa ibunya, yaitu bahasa

7. Mikhael Dua, Keutamaan, Diri Naratif, dan Tradisi Sebuah Refleksi Sejarah Moral Alasdair Maclntyre.Dalam Moralitas Lentera Peradaban Dunia. Andre Ata Ujan, Febiana R. Kainama, T. Sintak Gunawan (Ed.). Yogyakarta: Penerbit Kanisius, 2011, hlm. 43-65. 
Jerman. Beberapa karya yang memperlihatkan keberakarannya pada filsafat skolastik, teristimewa filsafat Thomas Aquinas dapat disebutkan berikut ini. Karya "Guide to Thomas Aquinas" berisikan hidup dan pemikiran filosofis Thomas Aquinas. Karya "Scholastik. Gestalten und Probleme der mittelalterlichen Philosophie" berbicara tentang Filsafat Skolastik, Sosok dan Problem Filsafat Abad Pertengahan. Karya yang lain "Thomas Aquinas The Cardinal Virtues: Prudence, Justice, Fortitude, and Temperance" memuat pemikiran Thomas Aquinas tentang keutamaan-keutamaan pokok seperti kecermatan sebagai keutamaan intelektual, keadilan, keteguhan dan keugaharian. Karya “The Silence of St. Thomas" berisikan tentang hidup dan kepribadian Thomas, elemen negatif dalam filsafat Thomas, dan penafsiran Pieper menyangkut relevansi pemikiran Thomas seturut tanda zaman.

Beberapa karya tentang konsep asli Pieper yang diilhami oleh pemikiran dasar Thomas Aquinas dapat disebut berikut ini. Karya "Faith, Hope and Love" diulasnya secara filosofis-teologis dalam satu kesatuan tentang iman, harap dan kasih. Karya "Tradition Concept and Claim" berbicara tentang konsep dan pandangannya tentang tradisi. Waktu senggang sebagai basis budaya diulasnya dalam karya "Leisure The Basis of Culture". Konsep tentang dosa ditulisnya dalam karya "The Concept of Sin". Karya "Death and Immortality" memuat filsafatnya tentang kematian dan kekekalan. Meditasi tentang Filsafat Sejarah dipaparkannya dalam buku "The End of Time", dan banyak tulisan lain yang tidak disebutkan di sini.

Gagasan Pieper tentang manusia masih berada pada alur pemikiran yang sama dengan gagasan Thomas Aquinas. Manusia diciptakan menurut gambaran Allah. Dalam ajaran moral kristiani, sosok manusia seperti itulah yang harus dicapai. Tetapi menurut Pieper, ajaran moral seperti itu pada era Thomas Aquinas terlalu menititberatkan apa yang harus dilakukan manusia, apa yang wajib dikerjakan manusia untuk mencapai tujuan tersebut, ketimbang menghayati bagaimana manusia harus berada dan hidup sebagai gambaran Allah. Ajaran etis Thomas menurut Pieper mengacu pada konsep tentang hakikat manusia sebagai pribadi yang baik, pribadi yang adalah gambaran Allah. Konsep Pieper tentang manusia sebagai gambaran Allah dirincikan 
dalam ulasannya tentang sosok ideal manusia kristiani. Buku kecil Pieper "The Christian Idea of Man" melukiskan sosok ideal manusia kristiani itu. ${ }^{8}$ Manusia sejati menurut Pieper adalah Yesus Kristus sendiri, sementara manusia Kristen sebagai pengikut Kristus adalah Kristus yang lain. Makna dari Kristus yang lain itu tidak lain dari pada kewajiban manusia Kristen untuk menjadi “sempurna” seperti Allah Bapak Yesus Kristus sempurna adanya. Konsep ini sesuai dengan pernyataan Kitab Suci "adalah sempurna seperti Bapakmu di surga sempurna adanya”. Tetapi konsep ini menurut Pieper harus membutuhkan penafsiran, karena tidaklah mungkin kesempurnaan manusia itu sama seperti kesempurnaan Allah. Betapa pun baik dan sempurna hidup manusia, terdapat ketidakserupaan yang maha besar antara manusia sebagai makhluk ciptaan yang terbatas, fana dan tidak sempurna dengan Allah pencipta yang maha sempurna, kekal dan maha kudus. Fakta empiris di lapangan menunjukkan bahwa manusia itu selalu tersandung dan jatuh dalam kerapuhan dan keterbatasannya.

Pieper mengemukakan pandangan Thomas Aquinas yang mengusung tujuh tese Thomas tentang manusia Kristen yang ideal. Tese pertama, seorang Kristen adalah seorang pribadi yang dalam imannya insyaf dan sadar akan realitas Tritunggal Mahakudus. Tese kedua, seorang Kristen melihat ke depan dengan penuh pengharapan akan adanya pengalaman kepenuhan dan keutuhan eksistensinya dalam kehidupan kekal. Tese ketiga, seorang Kristen dengan keutamaan teologis, yaitu kasih, perlu berpaling kepada Allah dan kepada sesamanya sambil membangun relasi kasih dengan Allah dan sesama, relasi kasih yang jauh lebih kuat dari pada kasih kodrati manusiawi. Tese keempat, seorang Kristen harus bersikap hati-hati, bijak dan cermat (prudent), misalnya, ia tidak membiarkan pandangannya tentang sesuatu hal dikendalikan oleh pemaksaan kehendak tanpa mengacu pada kebenaran hal tersebut. Tese kelima, orang Kristen harus adil, misalnya, ia mampu hidup “dengan yang lain” dalam kebenaran; ia mampu melihat bahwa dia adalah salah satu anggota gereja, salah satu penduduk bumi dan salah satu anggota masyarakat dan negara. Tese keenam, seorang Kristen

8 Josef Pieper, The Christian Idea of Man. Indiana: St. Augustine's Press, 2011, hlm. 3-38. 
harus berani, misalnya, dia bersiap sedia untuk dianiaya, bahkan berani mengorbankan nyawa demi kebenaran dan keadilan. Tese ketujuh, seorang Kristen harus bersikap moderat dan seimbang (moderate), misalnya, dia tidak membiarkan dirinya dikuasai oleh hasrat kelobaan akan harta milik dan kenikmatan yang merusakkan eksistensi dirinya.

Tujuh tese Thomas Aquinas itu dipandang Pieper sebagai sebuah teori keutamaan yang memuat penafsiran terhadap diksi-diksi Kitab Suci tentang kesempurnaan manusia kristiani. Tentu ketujuh tese itu tidak lain dari pada tiga keutamaan teologis, yaitu iman, harap dan kasih, dan empat keutamaan pokok, yaitu kehati-hatian atau kebijakan atau kecermatan (prudence), keadilan (justice), keberanian atau keteguhan dan takut akan Allah (fortitude and fear of the Lord), dan keempat disiplin dan moderasi (moderation). Menurut Pieper, keutamaan-keutamaan itu dewasa ini tampak melemah dan layu, terutama empat keutamaan pokok, yang kurang diminati dalam hidup praktis orang Kristen.

Pieper mendalami makna kata "keutamaan" (virtue) yang dewasa ini jarang dibicarakan dalam percakapan harian. Proses sekularisasi dan dekristianisasi di Eropa berhasil menurunkan makna luhur kata "keutamaan" ke dalam kata kosong yang hanya menjadi milik ulasan teologis-dogmatis. Padahal, kata "keutamaan" sebagaimana disebut Thomas sebagai "ultimum potentiae" (tingkat tertinggi kemampuan) bermakna pemenuhan kemampuan manusia untuk berada baik dalam arti kodrati-manusiawi maupun dalam arti ilahi-adikodrati. Ia merupakan kualitas tertinggi kemampuan manusia untuk menghayati eksistensinya sebagai pribadi. Pribadi luhur (virtuous), yang menuruti kecenderungan batin yang paling dalam, justru berada dalam jalan untuk bertindak baik dan menghayati kebaikan melalui tindakannya. Keutamaan pertama dan terkenal yang harus menjadi milik manusia kristiani adalah kasih ilahi terhadap Allah dan sesama, karena Allah adalah kasih. Karena itu, terdapat hirarki keutamaan dari tingkat yang tertinggi, yaitu tiga keutamaan teologis dalam satu kesatuan (iman, harap dan kasih), lalu empat keutamaan pokok dengan urutan: kehati-hatian ( $p r u$ dence), keadilan (justice), keberanian (courage) dan kemoderatan atau keugaharian (moderate). 
Keutamaan "prudence" bila dihayati dapat menghasilkan semua keutamaan moral. Pribadi yang "prudent" pertama-tama mendengar dengan cermat lalu bersemangat untuk belajar "mengenal" realitas obyektif (kebenaran) lalu berkehendak untuk bertindak, karena realitas obyektif yang dikenal itu merupakan manifestasi kebenaran yang harus diwujudkan melalui tindakan. Jadi, keutamaan "prudence" tidak lain daripada kemampuan mendengar dengan cermat, mengenal secara obyektif kebenaran realitas dan bertindak demi kebenaran. Keadilan (justice) adalah kemampuan untuk hidup secara benar dengan "pribadi-pribadi yang lain". Keadilan merupakan seni untuk hidup bersama. Pribadi yang adil dapat dialami ketika keutamaan "prudence" dimilikinya. Pribadi yang adil ketika bertindak adil terhadap pribadi yang lain mengandung kemampuan untuk berada sebagai pribadi yang baik. Keadilan lalu merupakan bentuk tertinggi dan terasli dari pribadi yang baik. Keutamaan "keadilan" menyata dengan sempurna di dalam kosa kata "kita" dan bukan "kami", dan menurut Pieper kata "kita" yang di dalamnya keutamaan "keadilan" meraja, mengandung tiga elemen struktural. Pertama, keadilan yang bersifat komunikatif, yaitu bahwa relasi timbal balik antara anggota yang satu dengan anggota yang lain dalam "kita" sebagai satu masyarakat harus berjalan benar dan baik. Kedua, keadilan distributif, yaitu bahwa relasi keseluruhan "kita" sebagai satu komunitas dengan masing-masing anggota harus berjalan benar dan baik. Ketiga, keadilan yang bersifat legal, yaitu bahwa relasi setiap anggota dengan "kita" sebagai keseluruhan komunitas harus berjalan benar dan baik. Untuk menghayati keutamaan "keadilan" yang mencakup tiga elemen itu, memang terdapat berbagai macam teori sosial, tetapi prinsip tertinggi yang harus dipegang oleh semua pihak untuk bertindak adil ialah bonum communae, kebaikan bersama atau kesejahteraan umum.

Keberanian dan takut akan Allah merupakan keutamaan pokok kristiani dalam tingkat ketiga. Keberanian dalam bertindak hanya terwujud bila sasaran tindakan itu adalah untuk menegakkan kebenaran dan keadilan. Pribadi yang berani adalah orang yang bersiap sedia untuk dianiaya, bahkan rela dibunuh demi kebenaran dan keadilan. Itulah keberanian kristiani. Keberanian seperti ini tidak sama dengan tindakan agresif tanpa takut. Tindakan agresif tanpa takut bukanlah satu keutamaan, karena sasaran 
tindakan itu adalah ketakutan akan kehilangan eksistensi diri dan bukannya penegakan kebenaran dan keadilan. Dalam hubungan dengan ketakutan, keutamaan kristiani yang lain adalah takut akan Allah. Ketakutan semacam ini bersifat kodrati, dalam arti bahwa ada tingkatan atau hirarki ketakutan kodrati-alamiah (ordo timoris). Takut akan Allah adalah tingkat tertinggi ketakutan kodrati-alamiah akan keterpisahan eksistensi diri manusia dengan akar atau sumber terdalam keberadaan manusia, ketakutan akan anihilasi atau juga peniadaan eksistensi diri secara kekal, ketakuatan akan kehilangan eksistensi diri secara tetap. Bahasa teologis menyebutnya sebagai ketakutan akan kehilangan kasih Allah terhadapnya secara kekal. Etika kristiani yang dibangun atas dasar keutamaan "takut akan Allah" membutuhkan kekuatan adikodrati (rahmat Allah) yang memungkinkan manusia mampu berada dan bertindak sebagai pribadi yang baik, benar dan adil.

Keutamaan pokok keempat adalah moderasi atau keugaharian. Keutamaan ini berhubungan dengan kehidupan sensual seperti hasrat dan nafsu yang bersifat kodrati-alamiah. Pada umumnya hasrat dan nafsu dipahami secara negatif sebagai yang bertentangan dengan roh, dan manusia harus memangkasnya dengan keutamaan kemurnian (chastity), disiplin diri dan pantang (abstinence). Tetapi hasrat dan nafsu sesungguhnya tidak berkarakter moral, bisa merugikan manusia tapi bisa juga menguntungkan dan membahagiakan manusia. Hasrat dan nafsu sesungguhnya berada pada ranah pribadi dan hanya menyentuh kehidupan pribadi. Pieper mengangkat konsep Thomas tentang keutamaan keugaharian dengan menyebutnya sebagai "passiones animae" (passions of the soul), yaitu hasrat jiwa atau semangat hati yang menggerakkan kemampuan sensual seperti hasrat untuk mencinta, hasrat untuk membenci, hasrat untuk menikmati dan sebagainya. Sebagai satu keutamaan, hasrat ini berperan sebagai obat mujarab untuk menyembuhkan rasa sakit dan kesedihan.

Empat keutamaan pokok itu (prudence, justice, courage and moderation) berada pada tataran kodrati-manusiawi. Dalam konteks keutamaan kristiani, keempat keutamaan itu bertumbuh keluar dari tanah subur yang menjadi milik keutamaan teologis, yaitu iman, harap dan kasih dalam satu kesatuan. Iman, harap dan kasih adalah respons manusia Kristen terhadap Allah Tritunggal Maha Kudus yang diwahyukan kepada orang Kristen 
dengan cara adikodrati, yaitu melalui peristiwa revelasi Allah dalam diri Yesus Kristus. Ketiganya bukan hanya merupakan respons orang Kristen terhadap Tritunggal Maha Kudus, tetapi juga pada waktu yang sama merupakan kapasitas dan sumber kekuatan yang dibutuhkan untuk mempraktekkan dan menghayati iman, harap dan kasih. Melalui iman, manusia Kristen percaya akan realitas Allah Tritunggal Maha Kudus yang melampaui dan meluhurkan kesadaran serta kekuatan kodrati manusia. Melalui keutamaan harapan, manusia Kristen menjawabi kenyataan yang diwahyukan kepadanya, bahwa Yesus Kristus adalah “Jalan” menuju kehidupan kekal. Melalui kasih akan Allah dan akan sesama, manusia Kristen menjawabi rahmat kasih Allah yang mewahyukan diri-Nya sebagai "Kasih". Tiga keutamaan teologis ini tidak dapat dipisahkan dan berhubungan satu sama lain dalam satu kesatuan.

\section{Persahabatan dalam Perspektif Filsafat Yoseph Pieper}

Yoseph Pieper tidak mengulas topik persahabatan secara langsung dan tersendiri dalam tulisannya. Topik ini direfleksikan dari gagasan Pieper tentang manusia yang ideal. Persahabatan dalam terang pemikiran Yoseph Pieper dibangun di atas konsep biblis tentang manusia sebagai gambaran Allah. Kamus Besar Bahasa Indonesia menyebut persahabatan sebagai persaudaraan. Karena persahabatan itu secara empiris dialami dalam relasi antara manusia yang satu dengan manusia yang lain, maka persahabatan dari sananya merupakan salah satu bentuk tindakan manusia untuk berelasi dengan sesamanya. Tetapi karena manusia itu mempunyai sisi ilahi, maka persahabatan tidak semata-mata bersifat kodrati dan manusiawi. Ada karakter ilahi, suci dan kudus di dalam etika persahabatan. Bahasa teologis dalam diskursus Pieper tentang manusia mengungkapkan bahwa etika persahabatan merupakan jalan Allah yang bertindak di dalam diri manusia dan sekaligus juga kegiatan manusia di dalam Allah. ${ }^{9}$ Bahasa filsafat dalam diskursus Pieper tentang manusia menunjukkan bahwa persahabatan merupakan kegiatan manusia yang mengacu pada prinsip meta-etis sebagai

9 Ibid, hlm. 39. 
tindakan Sang Ada dalam mewahyukan diri-Nya kepada manusia.

Karena persahabatan memiliki karakter kodrati-manusiawi dan sekaligus karakter adikodrati-ilahi, maka berbicara tentang persahabatan dalam perspektif filsafat Pieper berarti berbicara tentang karakter-karakter manusia ideal yang mencerminkan persahabatan yang sejati. Karakterkarakter manusia ideal itu berakar pada tiga keutamaan teologis dan empat keutamaan pokok. Karena itu, atas dasar tiga keutamaan teologis dan empat keutamaan pokok tersebut persahabatan yang sejati menurut perspektif Pieper haruslah dijalankan oleh manusia sebagai pribadi yang beriman, pribadi yang berharap, pribadi yang mencinta, pribadi yang bijak dan cermat ( $p r u$ dent), pribadi yang adil, pribadi yang berani dan takut akan Tuhan, pribadi yang ugahari (moderate). Yoseph Pieper mengulas keutamaan-keutamaan itu dalam perspektif filosofis-teologis, tetapi tulisan ini lebih menampilkan perspektif filosofis dari pada perspektif teologis (teologi kristen) untuk menonjolkan keutamaan-keutamaan persahabatan sebagai karakter-karakter universal-humanis yang mengacu pada prinsip meta-etis.

Persahabatan dijalinkan oleh manusia yang beriman. ${ }^{10}$ Satu kenyataan universal-humanis yang ditemukan di dalam diri manusia tanpa kecuali adalah bahwa semua orang memiliki iman. Iman atau kepercayaan melekat secara kodrati dan esensial pada pribadi manusia. Kaum Atheist yang percaya bahwa tidak ada Tuhan Allah pun memiliki iman tertentu. Yang menjadi soal ialah jawaban manusia terhadap pertanyaan: apa yang diimani atau siapa yang diimani. Di sanalah letak perbedaan dan keanekaragaman pandangan dan kepercayaan manusia. Isi iman atau sasaran iman memang berbeda dari orang ke orang, dari kelompok yang satu ke kelompok yang lain atau dari kepercayaan yang satu ke kepercayaan yang lain. Orang yang beriman tentu memiliki pandangan dan pemahaman bahwa apa yang diimani atau siapa yang diimani sungguh benar dan baik. Dalam perspektif Pieper persahabatan dijalankan dalam relasi dan dialog antara subyek yang beriman dan sasaran imannya. Tetapi Pieper melihat bahwa relasi dan dialog subyek yang beriman dengan apa yang diimani bersifat

10 Josef Pieper, Faith - Hope - Love. San Fransisco: Ignatius Press, 1986, hlm. 19-85. 
tidak manusiawi dan impersonal (tidak pribadi). Iman yang sejati hanyalah berlaku antara subyek yang beriman dan subyek yang diimani. Dari perspektif ini, etika persahabatan lalu hanya bisa diwujudkan antara subyek yang beriman dan subyek yang diimani. Subyek yang diimani bukanlah manusia, karena bila subyek yang diimani itu manusia, maka karakter persahabatan hanyalah bersifat kodrati-manusiawi, terbatas dan penuh dengan kekurangan dan cacat. Bahasa teologis menyebut subyek yang diimani sebagai "Allah" yang mewahyukan diriNya kepada manusia dalam sosok manusia Yesus Kristus, dan bahasa filsafat menyebut subyek yang diimani sebagai Subyek transendental yang mewahyukan diriNya secara terus menerus dalam sejarah manusia. Persahabatan antara manusia hanya bisa bertahan bila bertumpu di atas relasi persahabatan antara manusia dan subyek transendental itu.

Persahabatan dijalinkan oleh manusia yang berharap. ${ }^{11}$ Harapan adalah sebuah fakta humanis yang terdapat dalam diri semua orang, terkecuali mereka yang kehilangan harapan atau putus asa. Dalam arti kodrati, harapan mengacu pada sesuatu yang belum terwujud atau sesuatu yang belum terpenuhi. Keutamaan harapan boleh dikatakan sebagai keutamaan "belum" (not yet). Manusia yang berharap adalah manusia yang sedang "berjalan atau mengembara" di dunia menuju dunia di balik dunia kodrati ini, dunia supranatural yang "belum" terwujud di dunia ini. Persahabatan dalam perspektif ini dipahami sebagai relasi antara manusiamanusia yang mempunyai harapan untuk mencapai dunia yang belum terwujud di dunia ini. Tetapi perspektif Pieper mengunggulkan konsep teologis. Keutamaan harapan menandakan cinta kasih yang tidak sempurna dari manusia terhadap Allah, dan keutamaan ini hanya dihayati melalui doa kepada Allah dalam pengembaraannya di dunia ini menuju masa depan yang tidak pasti dalam pengalaman manusia di dunia. Yesus Kristus menurut Pieper adalah dasar aktual harapan untuk manusia kristen. Persahabatan yang dijalankan antara manusia dalam dimensi horizontal tidaklah menunjukkan persahabatan sejati. Persahabatan sejati antara manusia yang berharap hanya bisa dibangun di atas dasar kasih yang tidak sempurna dari manusia terhadap Allah sebagai respons terhadap kasih Allah yang sempurna terhadap

11 Ibid, hlm. 91-138. 
manusia (dimensi vertikal). Melalui doa, persahabatan sejati yang dihayati oleh manusia-manusia yang berharap di dalam pengembaraan di dunia mencapai pemenuhan dan penyempurnaannya di masa depan di kehidupan yang kekal. Konsep tentang persahabatan sejati yang dijalankan oleh manusia yang berharap justeru berdampak pada sikap etis manusia terhadap manusia lain, yaitu sikap murah hati dan rendah hati.

Persahabatan dijalinkan oleh manusia yang mencinta. ${ }^{12}$ Bahasa Indonesia mengenal beberapa kata seperti "cinta, kasih, cinta kasih, kasih sayang, rasa sayang” untuk menunjuk kepada kegiatan manusia yang mencinta. Bahasa Latin mengenal dua kata, yaitu "amor" dan "caritas", dan dalam tradisi iman kristiani dikenal ungkapan "Ubi caritas est amor, Deus ibi est" (Di mana ada cinta kasih, di sana Allah ada). Pieper menyebut dua kata bahasa Yunani, yaitu eros dan agape, dan dua kata bahasa Inggris "love, charity" untuk menunjukkan kegiatan manusia yang mencinta. Persahabatan merupakan salah satu bentuk relasi yang dibangun oleh manusia yang mencintai. Dalam pemahaman tentang persahabatan yang bersifat kodrati-manusiawi, cinta bertolak dari cinta-diri sebagai kegemaran atau kesukaan akan sesuatu atau akan seseorang (sasaran cinta). Pieper mengutip perkataan Aristoteles dalam karya Aristoteles "Nichomachean Ethics": "Relasi-relasi yang mengartikan berbagai macam persahabatan rupanya berasal dari relasi-relasi terhadap diri kita sendiri". ${ }^{13}$ Pieper mengutip lagi perkataan Thomas Aquinas yang bergaul dengan filsafat Aristoteles: "Seorang sahabat dicintai seperti seseorang yang untuknya kita rindukan sesuatu; dan manusia juga mencintai dirinya justeru persis dengan cara yang sama." 14

Tetapi keunggulan filsafat Pieper tentang makna persahabatan terletak dalam pemahamannya tentang cinta sebagai sebuah keutamaan teologis, yang menjiwai etika persahabatan manusia. Manusia perlu bersahabat

12 Ibid, hlm.145-281.

13 "The relations that serve to define the various kinds of friendship seem to be derived from our relations to ourselves". Ibid, hlm. 236.

14 "A friend is loved as one for whom we desire something; and man also loves himself in exactly way this same way". Ibid, hlm. 236. 
dengan Allah dengan membangun relasi cinta akan Allah dengan seluruh pribadi manusia, dan konsekuensinya, manusia harus bersahabat dengan manusia lain dengan mencintai mereka sebagai bukti cinta manusia akan Allah. Dengan demikian, persahabatan yang dibangun atas cara ini bersifat ilahi dan dipandang sebagai persahabatan sejati yang melampaui persahabatan kodrati-manusiawi. Cinta yang menjiwai persahabatan sejati inilah yang disebut cinta sejati, cinta ilahi atau agape. Akar dari keutamaan teologis ini ialah bahwa Allah adalah kasih yang mencerminkan kegemaranNya akan keberadaan manusia di atas dunia. Bahasa filsafat Pieper yang mendapat ilham dari filsafat Heidegger menyebut relasi cinta manusia dengan realitas Ada sebagai prinsip kebaikan dan kebahagiaan (prinsip meta-etis), dan persahabatan sejati merupakan relasi cinta antara subyek manusia sebagai realitas "ada" di dunia dan "Sang Ada Mutlak". Konsekuensi etis untuk manusia di dunia ialah bahwa bersahabat dengan manusia lain bukan demi cinta-diri, tetapi demi kebaikan dan kebahagiaan orang lain semata.

Empat keutamaan pokok yang dikemukakan oleh Thomas dan Pieper merupakan konsekuensi dari penghayatan terhadap tiga keutamaan teologis. Persahabatan sejati perlu dijalin oleh manusia-manusia yang "prudent" (cermat dan bijak). Itu berarti untuk menjalin relasi yang baik dengan sesama, setiap orang perlu mendengar dengan cermat, mengenal secara obyektif kebenaran yang mewujud dalam relasi itu dan bertindak demi kebenaran itu. Persahabatan sejati perlu dijalin oleh manusia-manusia yang bersikap adil terhadap satu sama lain. Itu berarti bahwa tutur kata dan tindakan selalu bersifat inklusif, dan itu jelas dalam ungkapan kata "kita". Persahabatan sejati perlu dijalin oleh manusia-manusia yang berani. Itu berarti bahwa seorang sahabat siap untuk menderita, berkorban, bahkan berani mati demi tegaknya keadilan dan kebenaran. Persahabatan sejati perlu dijalin oleh manusia-manusia yang ugahari (moderate). Itu berarti bahwa seorang sahabat selalu memilih jalan tengah untuk tidak jatuh dalam sikap ekstrim. Ia perlu bersikap toleran, damai dan ramah. Tidak bersikap berlebihan memuji-muji dan mengagung-agungkan keunggulan sahabatnya, tapi tidak juga bersikap mengecam dan menyepelekan kelemahan dan kekurangan sahabatnya. 


\section{KEPUSTAKAAN}

Audi, Robert (ed.). The Cambridge Dictionary of Philosophy. New York: Cambridge University Press, 1995.

Dua, Mikhael. Keutamaan, Diri Naratif, dan Tradisi Sebuah Refleksi Sejarah Moral Alasdair Maclntyre dalam Moralitas Lentera Peradaban Dunia. Andre Ata Ujan, Febiana R. Kainama, T. Sintak Gunawan (Ed.). Yogyakarta: Penerbit Kanisius, 2011.

Hadiwjono, Harun, Dr. Sari Sejarah Filsafat Barat 1. Yogyakarta: Penerbit Kanisius, 1980.

Honnefelder, L., Person und Menschenwuerde. Dalam Philosophische Propaedeutik Band 2: Ethik.Honnefelder/Krieger. Muenchen: Wilhem Fink Verlag, 1996.

Oelmueller Doelle-Oelmueller Geyer. Philosophische Arbeitsbuecher 7 Diskurs: Mensch. Muenchen: Wilhem Fink Verlag, 1990.

Pieper, Josef. The Christian Idea of Man. Indiana: St. Augustine's Press, 2011.

. The Christian Idea of Man. Indiana: St. Augustine's Press, 2011.

Wieland, G. Ethik als praktische Wissenchaft. Dalam Philosophische Propaedeutik Band 2: Ethik. Honnefelder/Krieger (Ed.) Muenchen: Wilhem Fink Verlag, 1996. 